\title{
31. A US perspective on China's external economic disputes in the past 40 years and in the coming 40 years
}

Wing Thye Woo ${ }^{1}$

There are many US perspectives on China. For the purposes of this chapter, the relevant distinction is between the United States-first perspective on China and the internationalist US perspective. ${ }^{2}$ In this chapter, we employ the internationalist US perspective.

This clarification is important because recent discussions about US-Sino economic interaction have been increasingly conflated with issues of US-Sino competition for global influence. This conflation between economic competition and geostrategic positioning is occurring globally, resulting in the increasing weaponisation of global economic transactions-for example, China banned the export of rare earth elements to Japan in 2010, ${ }^{3}$ the United States banned the export of high technology to the Chinese company ZTE in 2018 and Western Europe is enforcing trade sanctions on Russia.

The analysis of economic interaction is normally predicated on finding a win-win outcome based on the principle of 'willing buyer-willing seller' operationalised through profit maximisation. The analysis of geostrategic contests, on the other hand, is usually predicated on a zero-sum outcome. The increasing conflation of these two analyses is what has motivated us to title this chapter 'A US perspective on China's external economic disputes', rather than 'An economic perspective of China's external disputes'.

The distinction between the United States-first perspective and the internationalist US perspective is as follows: the former not only puts US interests above the interests of other communities, it also strives to maintain US supremacy in the management of world affairs. Blackwill and Tellis (2015: 4) offer a good example of the United States-first perspective on China:

1 The subject of this chapter deserves a book-length treatment to do it justice, but I am adhering to an 8,000word limit to be less boring. I thank Jeremy Lim, Yu Miaojie and Gao Kailin for their help with data, and am most grateful to Ligang Song, Elizabeth Buchanan, Xiaolan Fu and Jan Borrie for their advice and patience.

2 We chose the more awkward term 'United States-first' over 'America-first' because a United States-first proponent may not be a Trump acolyte.

3 King and Armstrong (2013) have raised doubts about the existence of the 2010 ban on rare earth exports. 
Because the American effort to 'integrate' China into the liberal international order has now generated new threats to U.S. primacy in Asia-and could result in a consequential challenge to American power globally-Washington needs a new grand strategy toward China that centers on balancing the rise of Chinese power rather than continuing to assist its ascendancy ... [There must be] the clear recognition that preserving U.S. primacy in the global system ought to remain the central objective of U.S. grand strategy in the twenty-first century.

The internationalist US perspective on China also puts primacy on US interests, but it recognises that long-run US interests are usually better served when the United States is working in partnership with the rest of the world to solve common problems such as climate change and financial contagion. The internationalist US perspective recognises and accepts the legitimate concerns of China regarding its national security and economic prosperity, but it will mobilise its allies to counter unreasonable Chinese actions to impose its will on others. The internationalist US perspective on China does not consider being number one in the global system a primary policy objective. ${ }^{4}$

\section{China's external economic disputes}

China's journey of external economic engagement has been marked by many disputes, and it is safe to predict that its future course will generate new ones. This chapter hopes to help reduce the intensity and frequency of future international economic disputes, in two ways.

The first is to draw lessons for how to better manage disputes by reviewing two protracted and bitter external economic disputes of the past 40 years: 1) the dispute over China's exchange rate policy and its chronically large trade surplus; and 2) the dispute over China's industrial policy.

The second way we hope to attenuate future disputes is to offer some suggestions on how external economic management should be conducted in the next 40 years as China actively expands its international economic connectivity programsfor example, the Regional Comprehensive Economic Partnership (RCEP) and internationalisation of the renminbi. The initiative from China's agenda for improving international economic connectivity on which we have chosen to focus is the Belt and Road Initiative (BRI).

4 Patriotism is definitely not a distinguishing characteristic of these two perspectives; only weak-minded scoundrels would introduce this term into the discussion of US-Sino economic engagement. (It was Samuel Johnson who said 'Patriotism is the last refuge of a scoundrel'. See: www.samueljohnson.com/refuge.html.) 
The BRI is representative of China's readiness to take on the role of a responsible stakeholder that Robert Zoellick (2005) had challenged China to undertake. But as China takes on this new role, the existing major powers have shown themselves to be uncomfortable with China's greater influence in the international arena. For example, some pundits have claimed that the true objective of China's infrastructure loan program is to lure poor economies into taking on more loans than they can service and then pressuring these indebted countries to support China's geostrategic interests (Bloomberg News 2018; Hodge 2018; Malinao 2018). This conspiratorial theory of debt-trap diplomacy heightens competition among the big powers and leads to international disputes. China clearly has its work cut out in the next 40 years to show that such suspicions about the BRI are unjustified.

Summarising some of this chapter's key conclusions, we find with regard to the occasional highly dramatic dispute over China's exchange rate and trade imbalance that they have frequently been marked by analytical confusion over the meaning of the term 'equilibrium exchange rate'. Second, China's trade imbalance reflects the economic conditions both in China and abroad, and the efficient and fair solution of the problem usually requires policy changes not only in China, but also in other major countries - notably, the United States. Our third conclusion is that the dispute over exchange rate alignment has served as a diversion from 1) addressing the underlying structural factors causing the trade imbalance, and 2) improving the inadequacy of US job transition programs that has exacerbated US unhappiness with the trade imbalance.

In terms of industrial policy disputes, the first conclusion is that the issue of forced technology transfers is largely a dispute about a large economy using its market power to benefit itself at the expense of its trade partners. The second conclusion is that this use of market power will normally be only temporary because of the almost inevitable retaliation by other large countries, which is why we do not see the imposition of optimum tariffs by large importers. The third conclusion is that the notion of national security commonly adopted in the debate over US trade policy is overly broad and short-sighted and, unless these two aspects are corrected in US understanding of national security, the economic dynamism of the United States will be damaged and US national security weakened in the long run.

In terms of the BRI, the first conclusion is that, as the number of BRI projects grows, and as the number of partner countries increases, the number of economic disputes involving China will grow. Second, China should ensure that BRI projects in each country are economically beneficial to the general population of that country and not politically biased just towards the government in power at the time. Unlike in China, in most countries, governments come and go relatively frequently. The third conclusion is that China must develop a good understanding of the economic problems and sociopolitical contradictions in recipient countries to be 
able to pre-empt or settle economic disputes. Fourth, disputes in general will arise when China starts displaying the overbearing, arrogant attitude that often guided the actions of big powers (such as the United States and Russia) in the past. Fifth, economic disputes are a systemic feature of the present uncoordinated multi-polar world.

\section{The dispute over China's chronic trade surpluses and exchange rate policy}

Figure 31.1 uses gross domestic product (GDP) to normalise the trade imbalance to provide a better measure of its impact on the economy. China's trade account surplus has been more than 2 per cent of GDP since 1996; it averaged more than 5 per cent in the period 2005-08 and reached 8.6 per cent in 2007. The relevant point is that China's trade surpluses in the past 20 years (1997-2016) have been not only persistent, but also large enough -3.8 per cent of GDP on averageto create much discontent in many developed countries, and particularly in the United States, about the displacement of labour by imports from China.

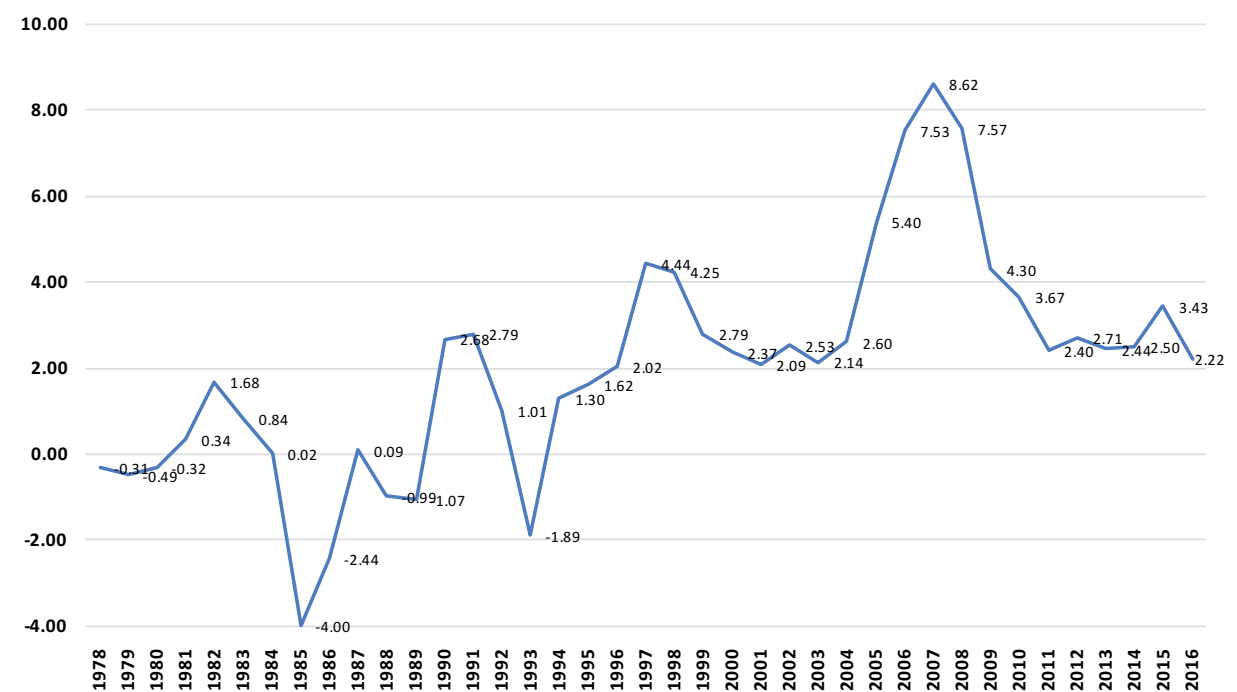

Figure 31.1 China current account balance (percentage of GDP)

Source: All China Data Center (chinadataonline.org). 
Figure 31.2 shows the overall US trade account balance and the bilateral United States-China trade account balance over the period 1992-2017..$^{5}$ The overall US trade account deficit enlarged rapidly, from 1.52 per cent of GDP in 1992 to a peak of 6.04 per cent in 2006. The overall US trade account deficit settled at about 4 per cent of GDP for the period 2013-17. The fact that the United States postGlobal Financial Crisis (GFC) continues to borrow a large amount annually from overseas suggests the overspending and undersaving in its economy are structural and not cyclical in nature. The outstanding practitioner of these twin traits is the Government of the United States, whose military expenditure continues to soar and whose taxes are cut to pay off the plutocrats who finance elections.

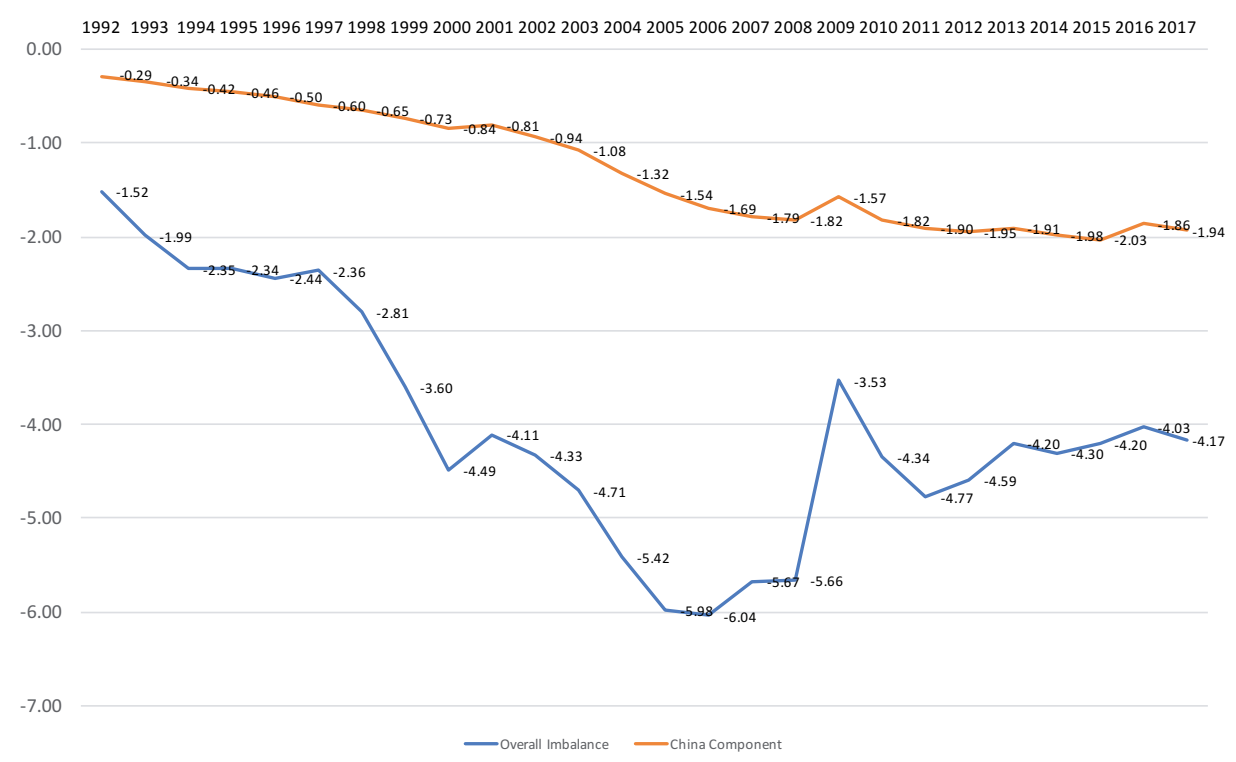

Figure 31.2 US trade balance in goods (percentage of GDP)

Source: US Census Bureau for trade data, US Government $(2013,2018)$ for GDP data.

Given the significant shrinkage of the overall US trade deficit after 2006, and the expansion of the bilateral US-Sino trade deficit after 2006, the latter now accounts for a much larger part of the former. The bilateral trade deficit grew from about 17 per cent of the overall US trade deficit in 1993-94 to 46 per cent in 2016-17. It is no wonder, then, that the policy community and general public in the United States have now been persuaded to regard Chinese imports as the major cause of the country's de-industrialisation.

5 This is the trade imbalance in the trade of goods. 
Much of the unhappiness among members of the US Congress and the public originates from the perception that China has cheated the international community in its management of external economic engagement. Specifically, many analysts have accused China of a mercantilist policy of keeping its currency, the renminbi, undervalued vis-à-vis the US dollar-that is, keeping the renminbi-US dollar exchange rate cheaper than the value of the equilibrium exchange rate.

\section{What is the correct level for the exchange rate?}

The economics profession defines the equilibrium market price of an item as the price that equates the supply with the demand for that item - that is, the equilibrium exchange rate is the market-clearing exchange rate in the absence of central bank intervention. So, even though the renminbi has appreciated substantially against the US dollar since China's system of multiple exchange rates was ended in 1994, the fact that the foreign exchange reserves of the People's Bank of China (PBC) have increased greatly over this period is prima facie evidence that the PBC has been preventing the renminbi from strengthening to its equilibrium (marketclearing) value.

While it is intellectually fulfilling to show conclusively that the renminbi is truly undervalued, the important information needed for policymaking is the degree of undervaluation. A renminbi undervaluation of 20 per cent will merit a policy response from the US Government, but an undervaluation of less than 8 per cent might not be worth reacting to.

There are two commonly used methods to compute the equilibrium exchange rate.

The first assumes values for the price elasticity of exports and imports, and then works back from the actual value of the exchange rate to the exchange rate that is consistent with a current account (CA) balance, which is equal in size but opposite in sign to a given capital account (KA) balance (for example, Goldstein 2006). The capriciousness of the size and the sign of this exogenously-set KA balance is obvious. Should the KA balance not be set according to the national objectives, economic conditions and the settings of the other policy instruments? We call the Goldstein-imputed exchange rate the 'equilibrium exchange rate under exogenous KA'.

The second popular way to calculate the equilibrium exchange rate is the purchasing power parity (PPP) approach, which posits 'that in the long run exchange rates should move towards the rate that would equalise the prices of an identical basket of goods and services ... in any two countries' (The Economist 2018). 
This view inspired The Economist magazine to construct a PPP exchange rate based on the prices of McDonald's Big Mac hamburgers sold in different countries. In January 2018, with the actual exchange rate at RMB6.43 per US\$1, it cost RMB20.4 to buy a Big Mac in China and US\$5.28 in the United States. So, is it meaningful to say that the Chinese exchange rate was undervalued by almost 40 per cent in January 2018?

The answer is no, because the prices of the hamburgers included nontradable inputs and the prices of nontradables were lower in China than in the United States. In general, the prices of nontradables are lower in developing countries than in developed countries because labour costs are lower in the former. With economic development, the prices of nontradables in the developing country will rise to bring its price ratio of nontradables to tradables in line with that in the developed country, and the equilibrium exchange rate will then equal the PPP exchange rate.

The fact that the PBC has been accumulating foreign reserves in almost every period means the renminbi is undervalued according to the 'market-clearing' definition. However, what would happen if China were to go further in its marketisation of foreign exchange transactions by opening its $\mathrm{KA}$ - that is, removing its capital controls? Diversification of asset portfolios by private Chinese agents would surely result in a great outflow of funds, possibly causing the renminbi to depreciate from its present value of RMB6.4 per US\$1 to, say, RMB6.8 per US\$1.

The reality is that China will inevitably open its KA, especially since it wishes to internationalise the renminbi to promote its use by non-Chinese residents. One could therefore reasonably argue that the correct equilibrium exchange rate to use is the 'equilibrium exchange rate under open KA'. The analytical importance for the debate on China's exchange rate is that the equilibrium exchange rate under open $\mathrm{KA}$ is weaker than the equilibrium exchange rate under exogenous $\mathrm{K}$ (i.e. the Goldstein-style imputed exchange rate) and the PPP exchange rate.

The correct way to think about exchange rate management is to analyse the issue within the context of overall macroeconomic management and not just its impact on the balance of payments. The general point is that because the balance of payments is only one of the main outcomes of concern and because the exchange rate is only one of the ways to affect the balance of payments, it is seldom optimal to concentrate exclusively on one policy target and then employ only one policy tool to achieve that single target. 


\section{Understanding the evolution of China's current account balance}

There are quite a number of China-centric explanations ${ }^{6}$ for China's chronic trade surplus, and we will discuss the two that seem the most credible:

1. the dysfunctional financial market theory, which attributes the imbalance to the inability of China's largely unreformed financial system to intermediate all savings into investment

2. the aggressive industrial policy theory, which attributes the trade imbalance to China's promotion of exports and suppression of imports.

The dysfunctional financial market theory focuses on the aggregate-level accounting identity that the overall CA balance is determined by the fiscal position of the government and the savings and investment decisions of state-controlled enterprises (SCEs). ${ }^{7}$ For the past decade, the Chinese fiscal position has been a small deficit, so it is not the cause of the swelling CA surpluses in the 2000s. The CA surplus exists because the sum of savings in SCEs and the private sector exceeds the sum of their investment expenditure, and it has expanded steadily because the nongovernment savings rate has been rising faster than the growth of nongovernment investment.

Why has China's financial system failed to translate savings into investment? This was not always the situation. Before 1994, the voracious absorption of bank loans by SCEs to invest recklessly kept the CA usually negative and the creation of nonperforming loans (NPLs) high. When the government implemented stricter controls on state-owned banks (SOBs) from 1994 onwards (for example, removing top bank officials if their bank loaned more than its credit quota or allowed the NPL ratio to increase too rapidly), the banks slowed the growth of loans to SCEs. This created an excess of savings because the SOB-dominated financial sector did not then rechannel the released savings (which were also increasing) to finance investment in the private sector.

This failure in financial intermediation by the SOBs is quite understandable. First, the legal status of private enterprises was, until recently, lower than that of state enterprises; and second, there was no reliable way to assess the balance sheets of

6 'China-centric' because they ignore the obvious fact that the current account balance is also determined by foreign, and notably US, economic conditions.

7 The SCE category covers companies that are classified as state-owned enterprises (SOEs), joint ventures and joint-stock companies, which are controlled by third parties (e.g. legal persons) who are answerable to the state. To understand how the principal-agent problem in SCEs has shaped China's macroeconomic performance, see Woo $(2006 ; 2017)$. 
private enterprises, which were naturally eager to escape taxation. The upshot was that the residual excess savings leaked abroad in the form of the CA surplus. Inadequate financial intermediation has made developing China a capital exporting country!

This perverse phenomenon in China is not new. Until the mid-1980s, Taiwan experienced this problem when all its banks were state-owned and operated under a civil service regulation that required each loan officer to repay any bad loan that they approved. The result was a massive failure in financial intermediation that caused Taiwan's CA surplus to be 21 per cent of GDP in 1986 . The reason China has not been producing the gargantuan CA surpluses seen in Taiwan in the mid1980 s is the still large amount of SCE investments.

The important point is that savings behaviour is not independent of the sophistication of the financial system (Liu and Woo 1994). An advanced financial system will have a variety of financial institutions to enable pooling of risks by providing medical, pension and unemployment insurance and to transform savings into education, housing and other types of investment loans to the private sector. Ceteris paribus, the more sophisticated a financial system, the lower will be the savings rate.

The second credible theory for China's chronic trade surplus is the aggressive industrial policy, which views China's anomalous trade imbalance as the unintentional outcome of, first, the overriding economic and political priority in China to create jobs for its underemployed (surplus) labour force; and second, widespread belief in the efficacy of infant industry protection-ambiguously labelled the 'promotion of indigenous innovation'-in accelerating China's movement up the value-added ladder. The resulting mix of export promotion and import suppression measures accelerated the simultaneous growth of export firms (which increased exports) and import competing firms (which decreased imports), and hence kept the trade balance in surplus. ${ }^{8}$

There is now adequate evidence, however, that a large component of China's industrial policy has actually reduced China's welfare in addition to enlarging its trade surplus, especially in the period 2008-17. Woo (2017) points out that the Chinese Government's practice of bailing out lossmaking SCEs caused the SCEs to overinvest, resulting in huge excess capacity in heavy industries and crowding out of the private sector. The former outcome led many SCEs to dump their products in foreign markets, which worsened China's trade imbalance. The return on equity (ROE) for SCEs dropped from 15.6 per cent in 2007 to 7 per cent in 2017. ${ }^{9}$

8 The explanation that the undervalued renminbi is responsible for China's trade imbalance is in fact an instance of the aggressive industry policy theory. The subsidy-tariff combination is equivalent to the undervaluation of a currency (see Woo 2004).

9 ROE data are from Cho and Kawase (2018). Also see Tan et al. (2016) for a discussion of China's zombie firms. 
Clearly, lowering the tension in trade disputes with the United States would require that:

- China accelerates the development of its financial sector if the dysfunctional financial market theory is correct

- China reduces export incentives and import barriers-especially from rentseeking industries with low rates of ROE if the aggressive industrial policy theory is correct.

Regardless of which theory is right, both actions should be undertaken because both enhance China's economic welfare, with one also lowering the probability of a trade war with the United States.

As to how the United States should react to China's subsidy-cum-tariff industrial policy, we begin by making two points. The first is that World Trade Organization (WTO) rules allow developing countries to engage in some protectionist measures to nurture their industrialisation. The second point is that China's industrial policies have only accelerated an economic development process that has been unfolding since 1978. The final outcome of low value-added industries in the United States being displaced by Chinese imports is inevitable because the United States is a capital-rich country and China is a labour-rich country.

The US policy package to deal with the closure of these low value-added firms due to Chinese exports should contain three elements in common with its policies to deal with the closure of low-tech firms due to technological change:

1. a US unemployment insurance scheme that incentivises acceptance of low-wage jobs_-for example, a negative income tax system

2. widely accessible US job retraining programs that are effective

3. science, technology, engineering and mathematics (STEM) programs in US high schools and universities that are high quality and attractive to the average student.

It is a sad failure of US socioeconomic management that only highly flawed versions of these three programs are in operation, and that little effort has been made to improve them.

There is one big difference between the policy package to address job losses from increased imports and that addressing job losses from new technology. The difference is that tariffs can be imposed on imports, but injunctions cannot be put on technological progress. There is, therefore, a good case for a temporary tariff when the government needs time to start (or expand) an unemployment insurance scheme and a job retraining program for displaced workers. 
So far, we have identified an array of structural factors and macroeconomic policies behind the US and Chinese trade imbalances-for example, dysfunctional financial markets in China and large government budget deficits in the United States. Instead of insisting on renminbi appreciation as the primary method for reducing US unhappiness with trade deficits, it would be more efficient to:

- directly address the specific reasons behind the trade imbalance in each country

- strengthen the above three job transition programs to deal with the loss of lowskilled jobs in the United States.

\section{The competition for high-technology industries}

One proven, powerful way to increase economic prosperity is to increase productivity; and the proven way to increase productivity is innovation-technological, institutional and product innovation. It has therefore been standard practice for a growth-oriented government to strengthen the country's indigenous capacity to innovate and to accelerate the acquisition of innovations from abroad. These two activities are usually not independent of each other. The knowledge of how someone abroad has solved a problem could enable a local scientist to come up with an improvement to the original innovation. The more developed a country, the more likely it is that these two activities will interact synergistically.

The Chinese Government has been working diligently to transition China's economy to innovation-based growth, and it has achieved substantial progress on this front (see Fu 2015; Fu et al. 2016). China's latest plan for industrial upgrading is the 'Made in China 2025' (MC-25) initiative unveiled in 2015. MC-25 aims to establish China as a 'manufacturing powerhouse' with global dominance in new high-tech areas such as artificial intelligence, robotics, advanced microchips, new energy vehicles, aviation and space travel, autonomous driving systems, solar cells, machine tools, biopharmaceuticals, medical devices, telecommunication devices and electronic sensors. The first step in China's planned journey to global leadership in high technology is the achievement by 2025 of self-sufficiency in the materials and parts used in such high-tech products. Self-sufficiency is defined as local content making up 70 per cent of the product.

The ambitious range of high-tech products in MC-25 and its intended clustering of most parts of the production chain within China have sent tremors through the high-tech business community and governments in the rest of the world. Because there was a perception that China had previously used industrial policy instruments that were not WTO sanctioned to reach its present technological level, many US observers saw MC-25 as a Chinese Government-led drive to break 'international rules to build cutting-edge industries of the future' (Bradsher and Rappeport 2018). 
Peter Navarro, a policy advisor to US President Donald Trump, recently summed up his view of what China has been doing as follows:

In textbook economics, trade is a win-win ... [but] America's trade with China is as far from that model as the Earth is from Mars ... Why is the textbook model failing? The answer is ... [China's] state-directed investments, nonmarket economy, and disregard for the rule of law.

The problem's taproot is Chinese intellectual-property theft and the forced transfer of foreign technology as a condition of accessing China's market ... [which allowed] Chinese companies to move rapidly up the innovation curve at much lower cost than their foreign competitors, which must recoup the cost of research and development through higher prices. (Navarro 2018)

The view that is rapidly gaining influence is that the real dispute in US-Sino economic interaction is not the size of China's trade imbalance, but China's intellectual piracy. As David Joy, Chief Market Strategist for Ameriprise Financial, has said, forced technology transfer is 'actually the biggest issue, more even than currency valuation. Being forced to give up technology for access to [the] market is essentially blackmail' (Joy, quoted by Isidore 2012).

And Chuck Schumer, the minority leader in the US House of Representatives, has criticised the perennial focus of US administrations on the bilateral US-Sino trade deficit as asinine:

China's trade negotiators must be laughing themselves all the way back to Beijing ... They're playing us for fools - temporary purchase of some goods, while China continues to steal our family jewels, the things that have made America great: the intellectual property, the know-how in the highest end industries. It makes no sense.

(Bennett and Bender 2018)

US dissatisfaction with Chinese trade has now expanded from unhappiness over the loss of US jobs due to exchange rate manipulation by China to include discontent over the loss of future high-paying jobs in high-tech industries because of forced technology transfer to China.

We organise our evaluation of the recent round of charges of unfair trade practices against China by discussing the four main instruments of China's industrial policy identified by its critics: ${ }^{10}$

1. import restrictions (for example, tariffs, quotas)

2. production subsidies (for example, export subsidies, low-interest loans, cheap land, preferential tax rates)

10 The use of an undervalued exchange rate as an industrial policy tool has already been discussed adequately in the previous sections of this chapter. 
3. forced transfer of technology (for example, industrial espionage, demanding the surrender of production technology in exchange for market access, imposing local content requirements)

4. 'cradle-snatching' of new technology (for example, purchasing technology licences, funding start-ups in Silicon Valley, setting up research and development centres in technologically advanced countries).

\section{Import restrictions and production subsidies}

Because learning-by-doing is an irrefutable phenomenon, it is often used to justify the use of import restrictions to induce the establishment of a targeted new industry. Such examples abound in China: China's ban on Google created Baidu, its ban on Twitter created Weibo, its ban on WhatsApp created WeChat, its ban on PayPal created Taobao and its ban on eBay created Alibaba. While these bans are bad for those US companies, they could have increased consumer surplus worldwide because it is now commonly acknowledged that the services provided by WeChat and Alibaba are at least as good as those of WhatsApp and Amazon.

The establishment of the targeted new industry can also be induced by production subsidies. In some cases, the learning experience occurs effectively only when the production level is above a certain critical minimum. When this minimum is larger than the size of the domestic market, production subsidies could be employed to expand production beyond the minimum by exporting the surplus output.

As noted earlier, WTO rules allow developing economies to use tariffs and subsidies to nurture some types of new industries, especially technologically advanced industries. It is usually only in cases where subsidies are used to expand production beyond domestic demand, resulting in significant exports, that the impacted country has a convincing complaint about the exporting country's violation of WTO protocol.

However, because many observers regard China as unusually successful in raising its infant industries into globally competitive industries, President Trump has demanded reciprocity in US-Sino trade-that is, a Chinese firm can receive tariff protection (or a production subsidy) only if its US competitor is similarly protected by the US Government. China has emphasised its developing country status (its per capita income being less than one-third of US per capita income) and rejected President Trump's demand for reciprocity in trade.

After 40 years of rapid economic development, China's continued use of WTOsanctioned incentives to promote infant industries is no longer viewed sympathetically in the advanced countries. Former director-general of the WTO Pascal Lamy has pointed out that China is now not only the second largest economy in the world, but also the biggest producer of a wide range of products (such as cement and 
desktop computers) and concluded that it is dishonest for China to pretend that it is similar to India, Senegal or Botswana. He believes China still has to do more to 'ensure a level playing field between Chinese producers and foreign producers, whether they produce inside China or outside of China' (cited in Bradsher and Rappeport 2018).

Our discussion of China's use of import restrictions and production subsidies must not create the impression that they have been very beneficial for China's economic growth. This is because the present pervasive excess industrial capacity and the incongruous twin phenomena of inland ghost cities and coastal real estate bubbles are also products of China's production subsidy system. China's inability to enforce hard budget constraints on SCEs is now threatening the financial sector with an explosion of NPLs, and undermining overall total factor productivity growth through the crowding out of the private sector. It is therefore wrong to offer a glowing assessment of China's system of import restrictions and production subsidies as being good for China despite its successful nurturing of manufacturing powerhouses such as Hai Er and cutting-edge technology firms such as Huawei.

\section{Forced transfer of technology}

A foreign firm that wishes to sell its products in China is sometimes told that its market access is conditional on setting up production facilities in China in the form of a joint venture with a major government-linked company (which could become a future competitor in markets outside China). If it were Singapore instead of China that presented this choice to the foreign firm, the foreign firm could well decide to forgo the small Singapore market. But because the Chinese market is very large and because other competing foreign firms are also seeking access to China's market with similar technology, a foreign firm will be more willing to trade its production technology for monopoly access to China's market.

The outcome of the above practice by China is the equivalent of getting a lower price for the foreign product in the long term, which is very similar to the bulk discount that big buyers are able to extract from their suppliers, and very similar to the 'optimum tariff that a large importer is wont to impose on its trade partner. In essence, the buyer in both cases is using their market power to extract a lower price for the product.

As the principle of 'willing buyer-willing seller' holds in the two examples above, it may seem a strange use of language to call this voluntary transaction a 'forced transfer of technology'. This language is justified only if the real picture of the use of such market power is akin to a schoolyard setting in which a big boy is demanding a bite of a small boy's sandwich. The universal schoolyard parlance to describe the big boy is 'a bully'. 
Is the exercise of market power always an act of bullying? Frankly, we are not sure. But for those who are sure that it is, Martin Feldstein (2018) is correct in describing the willing buyer-willing seller defence of this Chinese method of acquiring technology as 'disingenuous'.

US firms have long complained quietly but bitterly to US Government officials about China's use of its market power to pay an effectively lower price for goods. As mandated technology transfer contravenes WTO rules on market access, the US Government could have helped these US firms out earlier by either filing a formal complaint to the WTO or confronting China with an ultimatum to stop the use of its market power or face retaliatory action such as a US ban on exports of high-tech inputs to China.

The readiness of the injured party to retaliate is most likely the reason we do not see newspaper reports on the use of optimum tariffs by large countries. The expectation of retaliation is what keeps acts of economic aggression such as optimum tariffs in check.

It is therefore a puzzle that it is only now that the US Government is willing to take action against China's economically aggressive act of forced technology transfers. The answer to this puzzle is complicated because it involves several factors coming together to create the critical mass of political pressure to spur the government into action.

The past reluctance to act could have been influenced by factors such as:

- the absence of a coordination mechanism among competing foreign firms to collectively reject China's demands and collectively request their governments to file WTO complaints

- the perception by the US Government that the technology involved is not frontier technology that is critical for overall US competitiveness or national security

- bureaucratic inertia and incompetence

- the importance of China as an ally in international affairs

- possible liberal guilt about China's poverty and previous Western transgressions against China.

The recent turnaround in US policy on mandated technology transfers is likely due to a combination of developments:

- the technology that China is now demanding is truly frontier technology that is necessary for the development of the next generation of high value-added products

- the recognition that China is turning out to be more of a strategic competitor than a potential strategic partner

- the sense that China should not be treated like a developing economy because it has, after all, become the biggest aid donor to Africa and many parts of Asia. 
Given the inevitability of retaliatory action by the advanced economies, led by the United States, and the fact the exercise of market power is instinctively regarded as bullying behaviour, China should stop using its market power to exact technology transfers to avoid a trade war with the United States and its allies. This new behaviour is the same as the non-imposition of optimum tariffs by large countries. A new phase in China's use of industrial policy tools has arrived.

\section{Cradle-snatching of new technology}

The Committee on Foreign Investment in the United States (CFIUS) is an interagency body that reviews transactions that would give control of a US firm or technology to a foreign entity and rejects those that would hurt US national security. The truth is that CFIUS faces extreme difficulties in doing its job well, and this point is brought home most glaringly when one considers the following two cases.

Case 1: CFIUS will approve transactions for which the product/technology has no military applications and reject transactions for which the product/technology has military applications. However, most products and technologies can be weaponised. A terrorist can drive a car into the crowd leaving a rock concert. A KGB agent could place advertisements for vodka on a website she bought or she could post fake news to help get Donald Trump elected for a second term.

Case 2: The level of a country's national security depends on the quality of its weapons. The richer the country, the higher is the quality of weapons that it can afford. Since economic power is the basis of national security, should CFIUS ever approve the sale of any productivity-enhancing technology to Russian firms?

In short, if CFIUS is to take its job description literally, 'CFIUS really should be managing all global trade'. ${ }^{11}$

The MC-25 program states explicitly that it will seek to buy the next generation of high-technology products_-for example, by buying promising start-ups. There is, therefore, great fear in the United States and other advanced countries that the next generation of high technology could be appropriated by Chinese firms, possibly even through unfair means. Laskai (2018) reported:

Circumstantial evidence confirms this suspicion ... Take the example of Fujian Grand Chips, a purportedly private Chinese company that attempted to acquire German machine maker Aixtron in 2016. Shortly before it staged a public takeover of Aixtron, another Fujian-based company San'an Optoelectronics canceled a critical order from Aixtron on dubious grounds, sending its stock tumbling and presenting Fujian Grand Chips with an opportunity to swoop in. Both Fujian Grand Chips and San'an Optoelectronics shared a common investor: an important national

11 Observation by Paul Rosenzweig, former CFIUS staff member, cited in Bennett and Bender (2018). 
semiconductor fund controlled by Beijing. The acquisition was stymied by an 11 thhour intervention by government officials but demonstrated how Beijing can drive investing abroad, often in a highly coordinated manner.

Given the possible conspiratorial nature of the actions of the two Chinese firms in the preceding example, one could be misled to conclude that there is paranoia in Washington, DC, today when one reads:

Senate Majority Whip, John Comity (R-Texas) regularly warns his colleagues that China is using private-sector investments to pilfer American technology. China has 'weaponized' its investments in America 'in order to vacuum up U.S. industrial capabilities from American companies ... [The goal is] to turn our own technology and know-how against us in an effort to erase our national security advantage'. (Bennett and Bender 2018)

Since Comity's use of the word 'pilfer' means to 'steal', it is befuddling when one reads that Peter Navarro (2018) sees the opposite outcome from China's purchases:

[China has been] targeting American companies based on strategic and military goals rather than pure economic considerations ... [and hence has been] often willing to pay distortive prices, far above what the free market would dictate.

This clash in perceptions of whether the Chinese are paying enough for American technology is not because there is no consistency in paranoia, but because Comity and Navarro's definition of national security is too broad-and too short-sighted.

Their definition is too broad because it automatically equates an increase in Chinese economic competitiveness with a decrease in US national security. Since Comity and Navarro do not want the United States to do anything to strengthen its economic competitors, they would restrain the technology-rich United States from selling technology-intensive goods to foreigners when economic theory shows that this has mutually beneficial outcomes.

The Comity and Navarro definition of national security is also short-sighted because US economic dynamism is reinforced when it faces foreign competition. The immediate short-term outcome in economic competition is a zero-sum game, but the long-run outcome is a win-win situation. This is the virtue of a modern private market system that works in concert with the provision of public goods by the government and with vigorous research in the basic sciences conducted by universities (which are competing against each for glory and funding).

The Comity and Navarro conception of national security is also based on the false notion that Chinese investors (and perhaps Chinese bureaucrats) are much smarter than the Japanese investors who flooded into the United States in the late 1980s and early 1990s, buying assets such as the Rockefeller Center in 1989-activity that frequently ended in tears. Furthermore, their perception of the threat from Chinese investment does not take into account the fact that most start-ups fail and that 
Chinese investors cannot afford to buy all the start-ups that bubble up in Silicon Valley, Silicon Forest, Silicon Alley and along Route 128-not to mention other technological centres outside the United States.

\section{Probable future external economic disputes with China}

A new international economic normal is asserting itself with the emergence of China and India as economic powerhouses alongside North America, Europe, Japan and Russia. This new international normal will be consolidated further as other large developing countries, such as Brazil, Indonesia and Nigeria, begin growing faster. The toppling of US hegemony by the emergence of a multipolar world has greatly heighted US concern about its national security.

President Trump's present trade wars on multiple fronts reflect both this heightened concern about national security and the hesitation of the United States in continuing to promote economic globalisation. Our prediction is that the settlement of the present US-Sino trade dispute will inevitably be followed by new disputes breaking out over other trade issues until the leaders of the different spheres of influence can agree to deepen multilateral free trade. Economic disputes are a systemic feature of an uncoordinated multipolar political order.

The new regional economic institutions that China is helping to establish-such as the Asian Infrastructure Investment Bank (AIIB) and the RCEP_-and the global economic connectivity it is trying to enhance through programs such as the BRI and the Shanghai Cooperation Council could strengthen economic globalisation and enrich the countries in its neighbourhood. However, as the number of BRI projects grows and the number of partner countries increases, the number of economic disputes in which China will be involved will climb.

There are many reasons for this outcome besides the fact that the increased interaction creates more occasions for disagreement. The government in a partner country might find it politically expedient to divert public attention away from its own internal policy failures using the alleged outrageous acts of a foreign bully. Or China might want to unite competing political factions within its borders by highlighting how it is being taken advantage of by some partner countries.

As China strengthens its leadership status in Asian affairs, it must develop adequate understanding of the economic problems and sociopolitical contradictions in other Asian countries so as to settle disputes with them. When China acquires this understanding of its neighbours, it will be able to appreciate the political earthquakes developing beneath the seemingly quiescent surface in some of these countries, and be prepared to prevent economic disputes occurring. 
For example, close identification with the foreign government of the day, when that government is highly disliked by its own people, paves the way to economic disputes when there is a change of government in that country. This necessitates that China:

1. keeps the various relationships it has with each country on separate tracks: government-to-government relations, business-to-business relations and peopleto-people relations

2. ensures that BRI projects benefit the general population in the host country and are not politically biased towards the government of the day.

The present state of China-Malaysia relations is an illustration of some of the points made above. China seemed unaware that the relationship between the Malaysian Government and its people was very different from that in China; and that although the Malaysian Barisan Nasional ${ }^{12}$ coalition had been in power for almost as long as the Communist Party of China, it actually had feet of clay.

The origin of today's China-Malaysia economic dispute lies in China's purchase of several overpriced power stations from the Malaysian sovereign wealth fund, 1-MDB, which had been bankrupted by embezzlement. ${ }^{13}$ This asset sale allowed $1-\mathrm{MDB}$ to meet the debt servicing that was coming due. About the same time, the Malaysian Government of prime minister Najib Razak awarded major contracts for two rail projects to Chinese construction companies: the high-speed rail (HSR) connecting Kuala Lumpur and Singapore and the railway linking the east and west coasts of peninsular Malaysia, the East Coast Railway Link. Both projects are part of the BRI.

When Najib Razak was voted out of office on 9 May 2018 (much to the surprise of the Chinese Embassy in Kuala Lumpur), the new government led by Mahathir Mohamad discovered it had inherited a much larger debt than that declared on the public record. One of the megaprojects the new government cancelled to contain the debt level was the Kuala Lumpur-Singapore HSR project.

The Chinese newspaper Global Times then published an article stressing the sanctity of signed contracts, reminding Malaysia of the huge financial penalty of cancelling the HSR project and warning that China had lots of profitable investment options elsewhere besides Malaysia (Hu 2018). While this was not an official article of the Chinese Government, most Malaysian analysts interpreted it as the opening shot of an economic dispute. This dispute has not escalated, but only because the new Malaysian Government has wisely decided not to respond.

12 The Barisan Nasional (National Front) is a large coalition centred on the three race-based political parties that formed the Alliance Party in 1957.

13 US Department of Justice (2017) is a court filing on 1MDB. 
Another major determinant of the frequency and intensity of future economic conflict between China and other countries is the attitude that is likely to guide China's actions. Disputes of all kinds will become more frequent when China starts making the same mistakes made by other world powers in the past. Economic exploitation, interference in internal affairs and arrogance are the seeds of economic and political disputes between countries.

\section{Conclusions}

The increasing conflation of economic analysis and national security considerations in the discussion of US-Sino economic engagement highlights the importance of the work of CFIUS. It needs to be immediately given a new operational mandate and the resources to conduct systematic examination of the relevant transactions occurring through multiple avenues-for example, bankruptcy courts and venture capital firms. The new mandate to CFIUS must not be broad in scope. There should be a defined list of technologies it will cover and this list should be updated every 18 months.

Finally, we want to register our opposition to the many recommendations to ban collaborative research with Chinese scientists (see Swanson and Bradsher 2018). This type of recommendation is akin to 'driving a bulldozer towards a rose garden' (Bennett and Bender 2018).

\section{References}

Bennett, C. and Bender, B. (2018), How China acquires 'the crown jewels' of US technology, South China Morning Post, 22 May. Available from: www.scmp.com/ print/news/china/diplomacy-defence/article/2147288/how-china-acquirescrown-jewels-us-technology.

Blackwill, R. D. and Tellis, A. (2015), Revising US Grand Strategy Toward China, New York: Council for Foreign Relations.

Bloomberg News (2018), Chinese port project could land Myanmar in debt trap, The Straits Times, 13 May. Available from: www.straitstimes.com/asia/se-asia/ chinese-port-project-could-land-myanmar-in-debt-trap.

Bradsher, K. and Rappeport, A. (2018), The trade issue that most divides US and China isn't tariffs, The New York Times, 26 March. Available from: www.nytimes. com/2018/03/26/business/china-us-trade.html.

Cho, Y. and Kawase, K. (2018), How China's state-backed companies fell behind, Nikkei Asian Review, 23 May. Available from: asia.nikkei.com/Spotlight/CoverStory/How-China-s-state-backed-companies-fell-behind. 
The Economist (2018), The Big Mac index: Global exchange rates, to go, The Economist, 17 January. Available from: www.economist.com/content/big-mac-index.

Feldstein, M. (2018), The next step for Chinese economic policy, Project Syndicate, 23 April. Available from: www.project-syndicate.org/commentary/china-wtomandatory-technology-transfer-by-martin-feldstein-2018-04.

Fu, X. (2015), China's Path to Innovation, Cambridge: Cambridge University Press. doi.org/10.1017/CBO9781107110953.

Fu, X., Woo, W. T. and Hou, J. (2016), Technological innovation policy in China: The lessons, and the necessary changes ahead, Economic Change and Restructuring 49(2-3): 139-57.

Goldstein, M. (2006), Renminbi controversies, Cato Journal26(2)(Spring/Summer).

Hodge, A. (2018), China's debt-trap diplomacy snares our Asian neighbours, The Weekend Australian, 13 January. Available from: www.theaustralian.com. $\mathrm{au} /$ news/world/chinas-debttrap-diplomacy-snares-our-asian-neighbours/newsstory/7c6b04ac4e473f96d9ff3b7ec5abe102.

Hu, W. (2018), Ditching Chinese-built high-speed rail project will carry high costs for Malaysia, Global Times, 31 May. Available from: www.globaltimes.cn/ content/1105043.shtml.

Isidore, C. (2012), US vs China: The trade battles, CNNMoney, 13 March. Available from: money.cnn.com/2012/03/13/news/international/china-trade/index.htm.

King, A. and Armstrong, S. (2013), Did China really ban rare earth metals exports to Japan?, East Asia Forum, 18 August. Available from: www.eastasiaforum.org/ 2013/08/18/did-china-really-ban-rare-earth-metals-exports-to-japan/.

Laskai, L. (2018), Why does everyone hate Made in China 2025? Blog post, Council on Foreign Relations, 28 March. Available from: www.cfr.org/blog/why-doeseveryone-hate-made-china-2025.

Liu, L.-Y. and Woo, W. T. (1994), Saving behavior under imperfect financial markets and the current account consequences, Economic Journal 104(424): 512-27. doi.org/10.2307/2234628.

Malinao, A. L. (2018), China's debt-trap diplomacy: Inquirer columnist, The Straits Times, 25 January. Available from: www.straitstimes.com/asia/se-asia/chinasdebt-trap-diplomacy-inquirer-columnist.

Navarro, P. (2018), China's faux comparative advantage, Wall Street Journal, 15 April. Available from: www.wsj.com/articles/chinas-faux-comparativeadvantage-1523817868. 
Swanson, A. and Bradsher, K. (2018), White House considers restricting Chinese researchers over espionage fears, The New York Times, 30 April. Available from: www. nytimes.com/2018/04/30/us/politics/trump-china-researchers-espionage.html.

Tan, Y., Huang, Y. and Woo, W. T. (2016), Zombie firms and the crowding-out of private investment in China, Asian Economic Papers 15(3): 32-55. doi.org/ 10.1162/ASEP_a_00474.

US Census Bureau (n.d.-a), Foreign trade: Trade in goods with China. Available from: www.census.gov/foreign-trade/balance/c5700.html.

US Census Bureau (n.d.-b), Business and industry: Time series/trend charts. Available from: www.census.gov/econ/currentdata/?program=FTD.

US Department of Justice (2017), United States District Court for the Central District of California. United States of America vs Certain rights to and interests in the Viceroy Hotel Group No. CV 17-4438, 15 June. Available from: www.justice.gov/opa/press-release/file/973671/download.

US Government (2013), Economic report of the president, Washington, DC: US Government Publishing Office. Available from: www.gpo.gov/fdsys/pkg/ERP2013/pdf/ERP-2013.pdf.

US Government (2018), Economic report of the president, Washington, DC: US Government Publishing Office. Available from: www.gpo.gov/fdsys/pkg/ERP2018/pdf/ERP-2018.pdf.

Woo, W. T. (2004), Serious inadequacies of the Washington consensus: Misunderstanding the poor by the brightest, in J. J. Teunissen and A. Akkerman (eds), Diversity in Development: Reconsidering the Washington Consensus, The Hague: Forum on Debt and Development.

Woo, W. T. (2006), The structural nature of internal and external imbalances in China, Journal of Chinese Economic and Business Studies 4(1): 1-20. doi.org/ $10.1080 / 14765280600551208$.

Woo, W. T. (2017), China's soft budget constraint on the demand side undermines its supply-side structural reforms, China Economic Review. doi.org/10.1016/ j.chieco.2017.09.010.

Zoellick, R. B. (2005), Whither China: From membership to responsibility?, Remarks to National Committee on US-China Relations, New York City, 21 September. Available from: 2001-2009.state.gov/s/d/former/zoellick/rem/53682.htm. 
This text is taken from China's 40 Years of Reform and Development: 1978-2018, edited by Ross Garnaut, Ligang Song and Cai Fang, published 2018 by ANU Press, The Australian National University, Canberra, Australia.

doi.org/10.22459/CYRD.07.2018.31 